\title{
Reactions of Acetylenes with Noble Metal Carbonyl Halides. Part 10.' Synthesis and $X$-Ray Structural Characterization of a New Substituted Diplatina-dioxapentalene Complex $\left[\mathrm{Cl}(\mathrm{CO}) \mathrm{Pt}\{\mathrm{CMe}=\mathrm{C}(\mathrm{COOMe}) \mathrm{C}(=0)\} \mathrm{PtCl}\left(\mathrm{PPh}_{3}\right)\right] \dagger$
}

\author{
Claudio Allevi, Roberto Della Pergola, Luigi Garlaschelli, and Maria Carlotta Malatesta* \\ Dipartimento di Chimica Inorganica e Metallorganica, Universita' di Milano, Via G. Venezian 21,20133 \\ Milano, Italy \\ Alberto Albinati \\ Istituto di Chimica Farmaceutica, Universita' di Milano, Viale Abruzzi 42, 20133 Milano, Italy \\ Fabio Ganazzoli * \\ Dipartimento di Chimica del Politecnico di Milano, Piazza Leonardo da Vinci 32, 20133 Milano, Italy
}

The complex cis- $\left[\mathrm{Pt}(\mathrm{CO})_{2} \mathrm{Cl}_{2}\right]$, in chloroform solution at room temperature, reacts with methyl 2-butynoate in the presence of water and carbon monoxide to give $[\mathrm{Cl}(\mathrm{CO}) \mathrm{Pt}\{\mathrm{CMe}=\mathrm{C}(\mathrm{COOMe}) \mathrm{C}(=\mathrm{O})\} \mathrm{Pt}(\mathrm{CO}) \mathrm{Cl}](1)$. Complex (1) is easily transformed into the related triphenylphosphine derivative $\left[\mathrm{Cl}(\mathrm{CO}) \mathrm{Pt}\{\mathrm{CMe}=\mathrm{C}(\mathrm{COOMe}) \mathrm{C}(=0)\} \mathrm{PtCl}\left(\mathrm{PPh}_{3}\right)\right]$ (2). A multinuclear $\left({ }^{1} \mathrm{H},{ }^{195} \mathrm{Pt}\right.$, and $\left.{ }^{31} \mathrm{P}\right)$ n.m.r. study of complex $(2)$ is reported. The analysis of the ${ }^{195} \mathrm{Pt}$ n.m.r. spectrum gave unambiguously the value ${ }^{3} \mathrm{~J}(\mathrm{Pt}-\mathrm{Pt})=818 \mathrm{~Hz}$. The crystal structure has been solved by Patterson and Fourier methods from counter data and refined by blocked full-matrix least squares to a final conventional $R$ of 0.0317 for 3795 independent observed reflections. Crystals of complex (2) are triclinic, space group $P \overline{1}$, with unit-cell dimensions $a=13.921(4)$, $b=10.386(3), c=10.006(3) \AA, \alpha=107.56(7), \beta=103.02(6), \gamma=94.36(6)^{\circ}$, and $Z=2$. The crystal contains discrete molecules of (2) with square-planar arrangements around the $\mathrm{Pt}$ atoms showing large angular distortions due to the two five-membered rings. The two fused metallacycles and the two co-ordination planes are essentially coplanar, giving a flat molecule. No interaction between the two metal centres is present $[\mathrm{Pt}(1) \ldots \mathrm{Pt}(2) 4.721(1) \AA]$. The bond distances between the metal atoms and the organic fragment are significantly different: the $\mathrm{Pt}-\mathrm{C}\left(s p^{2}\right)$ lengths are 1.944(7) and 1.996(9) $\AA$, with a trans chlorine atom in both cases, while the $\mathrm{Pt}-\mathrm{O}$ distances are $2.118(5)$ and $2.017(5) \AA$ trans to the phosphine ligand and to the terminally bonded carbon monoxide, respectively.

Reactions of $\left[\mathrm{Pt}(\mathrm{CO})_{2} \mathrm{Cl}_{2}\right]$ with acetylenes have been extensively studied and various types of products obtained, depending on the type of substituents on the alkyne triple bond. ${ }^{2-9}$ In particular, we have observed that acetylenes bearing alkoxycarbonyl groups give derivatives containing a five-membered ring through co-ordination of the oxygen of the carboxylate carbonyl group to platinum. ${ }^{4,5,8}$ With dialkoxycarbonylacetylenes $\left(\mathrm{RO}_{2} \mathrm{CC} \equiv \mathrm{CCO}_{2} \mathrm{R}, \mathrm{R}=\mathrm{Me}\right.$ or $\mathrm{Et})^{4,5}$ the $\sigma$-alkenyl derivative $\left[\mathrm{Pt}\left\{\mathrm{C}\left(\mathrm{CO}_{2} \mathrm{R}\right)=\mathrm{C}(\mathrm{Cl})(\mathrm{COOR})\right\}-\right.$ $(\mathrm{CO}) \mathrm{Cl}]$ (I) is formed, ${ }^{5}$ whereas an ionic complex, $\left[\mathrm{Pt}\left\{\mathrm{CC}(\mathrm{COOEt})=\mathrm{C}(\mathrm{Ph}) \mathrm{C}\left(\mathrm{CO}_{2} \mathrm{Et}\right)=\mathrm{C}(\mathrm{Ph}) \mathrm{O}\right\}(\mathrm{CO}) \mathrm{Cl}\right][\mathrm{Pt}(\mathrm{CO})-$ $\left.\mathrm{Cl}_{3}\right](\mathrm{II}){ }^{8}$ is produced with ethyl phenylpropiolate through dimerization of the acetylene and concomitant insertion of carbon monoxide. For the $\sigma$-alkenyl derivative and for the cyclocarbene complex it was impossible to grow a single crystal suitable for $X$-ray study and the structural formulation was therefore based on n.m.r. and i.r. spectroscopic evidence and on reactivity. ${ }^{4,5,8}$

In order to obtain a system suitable for multinuclear n.m.r. study and $X$-ray structural analysis and which contains the oxygen of an alkoxycarbonyl group co-ordinated to platinum

$\dagger$ 1-Carbonyl-1,2-dichloro- $\mu$ - $\left[2^{\prime}\right.$-methoxycarbonyl-1'-oxobut-2'-ene$1^{\prime}, 3^{\prime}$-diyl- $\left.C^{3^{\prime}} O^{1^{\prime}}\left(\mathrm{Pt}^{1}\right), C^{1} O^{2}\left(\mathrm{Pt}^{2}\right)\right]$-2-triphenylphosphinediplatinum.

Supplementary data available: see Instructions for Authors, J. Chem. Soc., Dalton Trans., 1988, Issue 1, pp. xvii-xx.<smiles>[R6]C1=[P+](Cl)(Cl)OC(C(=O)O)=C1Cl</smiles>

(I)

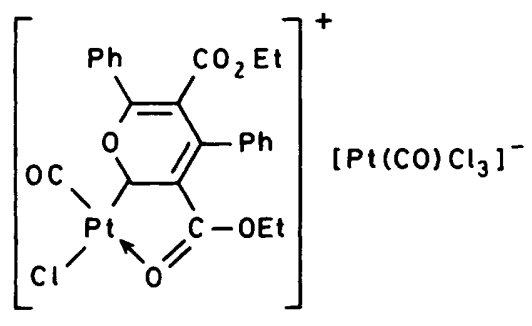

(II)

thus giving a five-membered ring, we have studied the reaction of $\left[\mathrm{Pt}(\mathrm{CO})_{2} \mathrm{Cl}_{2}\right]$ with methyl 2-butynoate and water which yields a yellow compound (1). We report the synthesis and the chemical characterization of (1) together with the preparation and an $X$-ray structural study of the analogous triphenylphosphine derivative (2). 
Table 1. Selected interatomic distances $(\AA)$ and angles $\left({ }^{\circ}\right)$ with estimated standard deviations (e.s.d.s) in parentheses for complex (2)

$\begin{array}{ll}\mathrm{Pt}(1)-\mathrm{Cl}(1) & 2.329(3) \\ \mathrm{Pt}(1)-\mathrm{P} & 2.217(2) \\ \mathrm{Pt}(1)-\mathrm{C}(6) & 1.944(7) \\ \mathrm{Pt}(1)-\mathrm{O}(1) & 2.118(5) \\ \mathrm{Pt}(2)-\mathrm{Cl}(2) & 2.338(3) \\ \mathrm{Pt}(2)-\mathrm{C}(2) & 1.996(9) \\ \mathrm{Pt}(2)-\mathrm{C}(7) & 1.804(9) \\ \mathrm{Pt}(2)-\mathrm{O}(3) & 2.017(5) \\ \mathrm{P}-\mathrm{C}(8) & 1.825(9) \\ \mathrm{P}-\mathrm{C}(14) & 1.816(8) \\ \mathrm{P}-\mathrm{C}(20) & 1.810(7)\end{array}$

$\begin{array}{lrll}\mathrm{C}(6)-\mathrm{Pt}(1)-\mathrm{O}(1) & 81.5(3) & \mathrm{Pt}(2)-\mathrm{C}(2)-\mathrm{C}(3) & 111.5(7) \\ \mathrm{P}-\mathrm{Pt}(1)-\mathrm{O}(1) & 173.9(2) & \mathrm{C}(2)-\mathrm{C}(3)-\mathrm{C}(6) & 116.3(8) \\ \mathrm{P}-\mathrm{Pt}(1)-\mathrm{C}(6) & 94.1(3) & \mathrm{C}(2)-\mathrm{C}(3)-\mathrm{C}(4) & 131.0(8) \\ \mathrm{Cl}(1)-\mathrm{Pt}(1)-\mathrm{O}(1) & 87.8(2) & \mathrm{C}(4)-\mathrm{C}(3)-\mathrm{C}(6) & 112.6(7) \\ \mathrm{Cl}(1)-\mathrm{Pt}(1)-\mathrm{C}(6) & 169.3(3) & \mathrm{C}(3)-\mathrm{C}(4)-\mathrm{O}(2) & 120.3(8) \\ \mathrm{Cl}(1)-\mathrm{Pt}(1)-\mathrm{P} & 96.6(1) & \mathrm{C}(3)-\mathrm{C}(4)-\mathrm{O}(1) & 119.7(8) \\ \mathrm{C}(7)-\mathrm{Pt}(2)-\mathrm{O}(3) & 178.5(4) & \mathrm{O}(1)-\mathrm{C}(4)-\mathrm{O}(2) & 120.0(8) \\ \mathrm{C}(2)-\mathrm{Pt}(2)-\mathrm{O}(3) & 81.7(3) & \mathrm{Pt}(1)-\mathrm{C}(6)-\mathrm{C}(3) & 113.5(6) \\ \mathrm{C}(2)-\mathrm{Pt}(2)-\mathrm{C}(7) & 97.5(5) & \mathrm{C}(3)-\mathrm{C}(6)-\mathrm{O}(3) & 115.6(7) \\ \mathrm{Cl}(2)-\mathrm{Pt}(2)-\mathrm{O}(3) & 90.3(2) & \mathrm{Pt}(1)-\mathrm{C}(6)-\mathrm{O}(3) & 130.8(6) \\ \mathrm{Cl}(2)-\mathrm{Pt}(2)-\mathrm{C}(7) & 90.5(4) & \mathrm{Pt}(2)-\mathrm{C}(7)-\mathrm{O}(4) & 176.6(10) \\ \mathrm{Cl}(2)-\mathrm{Pt}(2)-\mathrm{C}(2) & 171.8(3) & \mathrm{Pt}(1)-\mathrm{O}(1)-\mathrm{C}(4) & 112.6(6) \\ \mathrm{Pt}(1)-\mathrm{P}-\mathrm{C}(20) & 114.5(3) & \mathrm{C}(4)-\mathrm{O}(2)-\mathrm{C}(5) & 116.6(7) \\ \mathrm{Pt}(1)-\mathrm{P}-\mathrm{C}(14) & 115.8(3) & \mathrm{Pt}(2)-\mathrm{O}(3)-\mathrm{C}(6) & 114.7(6) \\ \mathrm{Pt}(1)-\mathrm{P}-\mathrm{C}(8) & 109.4(3) & \mathrm{C}-\mathrm{P}-\mathrm{C}^{*} & 105 \pm 3 \\ \mathrm{Pt}(2)-\mathrm{C}(2)-\mathrm{C}(1) & 123.5(7) & \mathrm{P}-\mathrm{C}-\mathrm{C}^{*} & 120 \pm 2 \\ \mathrm{C}(1)-\mathrm{C}(2)-\mathrm{C}(3) & 125.0(8) & \mathrm{C}-\mathrm{C}-\mathrm{C}^{*} & 120 \pm 1 \\ & & & \end{array}$

* Average.

\section{Results and Discussion}

A chloroform solution of $\left[\mathrm{Pt}(\mathrm{CO})_{2} \mathrm{Cl}_{2}\right]$ reacts with water under a carbon monoxide atmosphere to give the anionic platinum carbonyl clusters $\left[\mathrm{H}_{3} \mathrm{O}\right]_{2}\left[\mathrm{Pt}_{3}(\mathrm{CO})_{6}\right]_{n}(n \geqslant 10) .{ }^{10}$ Using the same conditions but in the presence of methyl 2-butynoate a yellow precipitate is obtained and the elemental analysis is in agreement with the formula given in equation (1). The best yield

$$
\begin{aligned}
& 2\left[\mathrm{Pt}(\mathrm{CO})_{2} \mathrm{Cl}_{2}\right]+\mathrm{MeC} \equiv \mathrm{CCO}_{2} \mathrm{Me}+\mathrm{H}_{2} \mathrm{O} \longrightarrow \\
& {[\mathrm{Cl}(\mathrm{CO}) \mathrm{Pt}\{\mathrm{CMe}=\mathrm{C}(\mathrm{COOMe}) \mathrm{C}(=\mathrm{O})\} \mathrm{Pt}(\mathrm{CO}) \mathrm{Cl}]+} \\
& \text { (1) } 2 \mathrm{HCl}+\mathrm{CO}_{2}
\end{aligned}
$$

is obtained by treating the chloroform solution of $\left[\mathrm{Pt}(\mathrm{CO})_{2} \mathrm{Cl}_{2}\right]$ with quantities of water and alkyne ester greater than that required by equation (1) probably because there are some side reactions between these two reagents catalyzed by $\left[\mathrm{Pt}(\mathrm{CO})_{2} \mathrm{Cl}_{2}\right]$ or $\mathrm{HCl}$. When a large excess of water is employed compound (1) is contaminated with $\left[\mathrm{H}_{3} \mathrm{O}\right]_{2}\left[\mathrm{Pt}_{3}(\mathrm{CO})_{6}\right]_{n}$. The carbon monoxide atmosphere prevents the reduction of $\left[\mathrm{Pt}(\mathrm{CO})_{2} \mathrm{Cl}_{2}\right]$ to platinum metal. The evolution of carbon dioxide, indicated in equation (1), was clearly evident from i.r. spectroscopic measurements and hydrogen chloride was found in the reaction vessel; the $\mathrm{HCl}$ is partially lost from the reaction flask and partially reacts with $\left[\mathrm{Pt}(\mathrm{CO})_{2} \mathrm{Cl}_{2}\right]$ to give, together with other by-products which are currently under investigation, the unstable $\left[\mathrm{H}_{3} \mathrm{O}\right]\left[\mathrm{Pt}(\mathrm{CO}) \mathrm{Cl}_{3}\right]$. The latter does not react with $\mathrm{MeC} \equiv \mathrm{CCO}_{2} \mathrm{Me}$, and can be recovered from the mother-liquor by transformation into the stable $\left[\mathrm{N}\left(\mathrm{PPh}_{3}\right)_{2}\right]\left[\mathrm{Pt}(\mathrm{CO}) \mathrm{Cl}_{3}\right]$.

Compound (1) is slightly soluble in $\mathrm{CHCl}_{3}$ and $\mathrm{CH}_{2} \mathrm{Cl}_{2}$, insoluble in hexane, and dissolves with decomposition in acetone, methanol, and acetonitrile. Its ${ }^{1} \mathrm{H}$ n.m.r. spectrum in $\mathrm{CDCl}_{3}$ consists of a pseudo-triplet at $\delta 2.8\left[\mathrm{CH}_{3},{ }^{3} J\left({ }^{195} \mathrm{Pt}-\mathrm{H}\right)=60\right.$ $\mathrm{Hz}$ ] and a singlet at $\delta 4.3\left(\mathrm{OCH}_{3}\right)$ with the correct integration
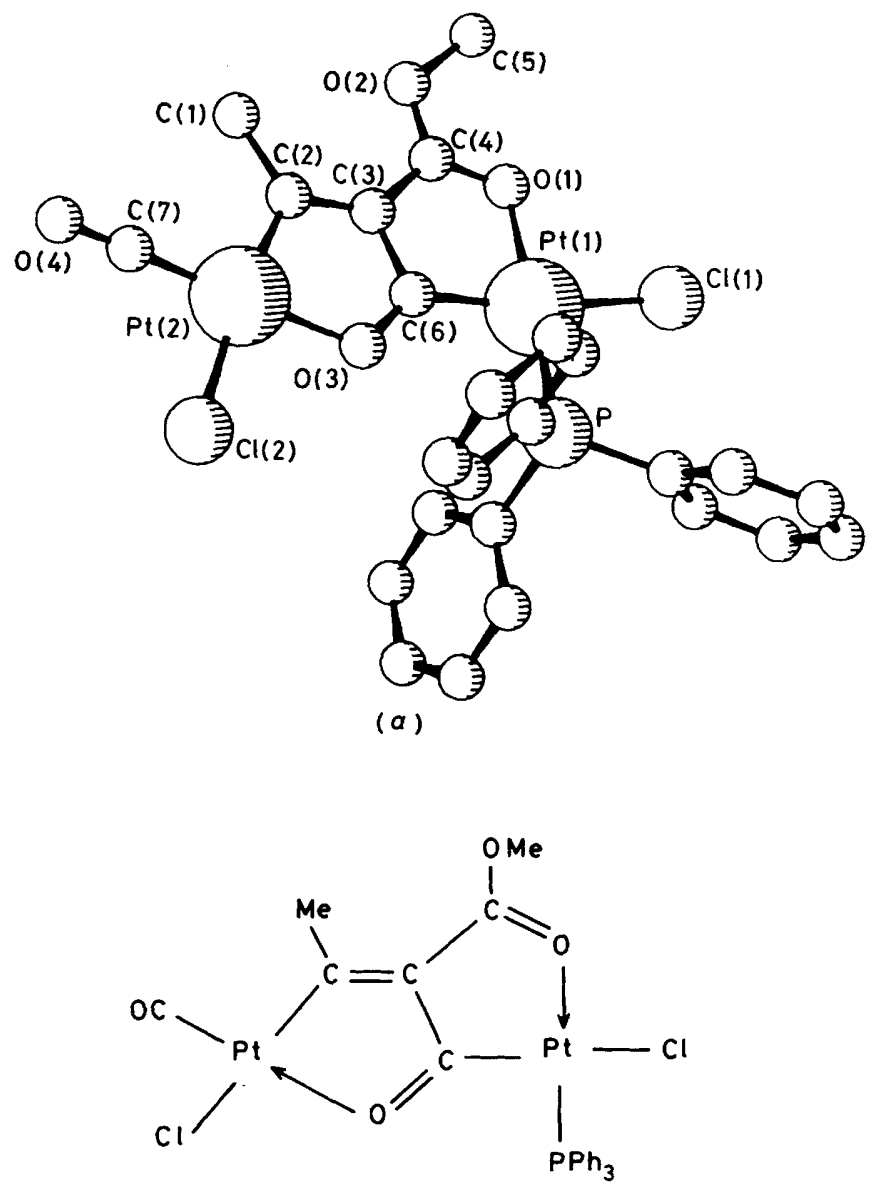

(b)

Figure 1. Perspective view (a) and line drawing (b) of complex (2)

for the formulation suggested. Complex (1) reacts rapidly with the stoicheiometric amount of $\mathrm{PPh}_{3}$ in tetrahydrofuran (thf) to give a yellow-green microcrystalline compound (2) which analyses as $\left[\mathrm{Cl}(\mathrm{CO}) \mathrm{Pt}\{\mathrm{CMe}=\mathrm{C}(\mathrm{COOMe}) \mathrm{C}(=\mathrm{O})\} \mathrm{PtCl}\left(\mathrm{PPh}_{3}\right)\right]$. Complex (2), soluble in $\mathrm{CHCl}_{3}$, thf, and toluene, is quite stable in solution, and can be recrystallized from dichloromethanehexane.

Molecular Structure of Complex (2).-A perspective view with the numbering scheme and a line drawing of compound (2) are given in Figure $1(a)$ and $(b)$, respectively, while relevant bond lengths and angles are reported in Table 1 .

The compound consists of two fused five-membered metallacycles with no direct interaction between the two platinum atoms $[\operatorname{Pt}(1) \cdots \operatorname{Pt}(2) 4.721(1) \AA]$. The platinum(II) atoms have the expected square-planar co-ordination defined in both cases by a $\sigma$-alkenyl carbon atom and a carbonylic oxygen, which are part of the two rings, and completed for $\mathrm{Pt}(1)$ by atom $\mathrm{Cl}(1)$ and the phosphine ligand and for $\mathrm{Pt}(2)$ by atom $\mathrm{Cl}(2)$ and by a terminally bonded carbon monoxide. The two metallacycles are planar to within $\pm 0.03 \AA$ and form a dihedral angle of $2.7(2)^{\circ}$. Furthermore, the co-ordination planes of the metal atoms and the least-squares planes through the corresponding metallacycles are almost coincident, making dihedral angles of $3.5(2)^{\circ}$ [planes $\mathrm{Pt}(1), \mathrm{Cl}(1), \mathrm{P}, \mathrm{O}(1), \mathrm{C}(6)$ and $\mathrm{Pt}(1), \mathrm{O}(1), \mathrm{C}(3), \mathrm{C}(4), \mathrm{C}(6)$ ] and of $1.6(2)^{\circ}$ [planes $\operatorname{Pt}(2), \mathrm{Cl}(2), \mathrm{O}(3), \mathrm{C}(2), \mathrm{C}(7)$ and $\mathrm{Pt}(2)$, $\mathrm{O}(3), \mathrm{C}(2), \mathrm{C}(3), \mathrm{C}(6)]$. As a result, if we neglect the phenyl rings of the phosphine ligand, the whole molecule is essentially flat: 
small deviations from planarity may be ascribed to the bulkiness of the triphenylphosphine ligand.

Large deviations from the ideal value of $90^{\circ}$ are found in the bond angles around the $\mathrm{Pt}$ atoms due to the strain imposed by the five-membered rings: for example, the angles $\mathrm{C}(6)-\mathrm{Pt}(1)-$ $\mathrm{O}(1)$ and $\mathrm{C}(2)-\mathrm{Pt}(2)-\mathrm{O}(3)$ [av. 81.6(3) ${ }^{\circ}$ are strongly compressed. The observed value falls in the range $79.5(5)-83.3(2)^{\circ}$ reported for related metallacycles. ${ }^{6,11-14}$ These angular distortions at the $\mathrm{Pt}$ atoms are also reflected in the other angles, most notably $\mathrm{Cl}(1)-\mathrm{Pt}(1)-\mathrm{C}(6)\left[169.3(3)^{\circ}\right]$ and $\mathrm{Cl}(2)-\mathrm{Pt}(2)-$ $\mathrm{C}(2)\left[171.8(3)^{\circ}\right]$.

The two $\mathrm{Pt}-\mathrm{C}\left(s p^{2}\right)$ distances are significantly different $[\mathrm{Pt}(1)-\mathrm{C}(6)$ 1.944(7) and $\mathrm{Pt}(2)-\mathrm{C}(2)$ 1.996(9) $\AA]$, although the trans ligand is a $\mathrm{Cl}$ atom in both cases; compared to the assumed single bond value ${ }^{15}$ of $2.02 \AA$, these values suggest a bond order greater than one, at least in the former bond. These distances may also be compared with those of 2.035(9) $\AA^{6}$ for $\left[\mathrm{Pt}\left\{\mathrm{C}\left(\mathrm{CO}_{2} \mathrm{Me}\right)=\mathrm{C}(\mathrm{Cl}) \mathrm{COO}\right\}(\mathrm{CO}) \mathrm{Cl}\right]^{-}$, or 1.991(6) $\AA^{12}$ for $\left[\mathrm{Pt}\left\{\mathrm{ON}\left(=\mathrm{CMe}_{2}\right) \mathrm{CH}=\mathrm{CMe}\right\} \mathrm{Cl}\left(\mathrm{PMe} \mathrm{Ph}_{2} \mathrm{Ph}\right)\right.$ and 1.97(2) $\AA^{5}$ for cis $-\left[\mathrm{Pt}\left\{\mathrm{C}\left(\mathrm{CO}_{2} \mathrm{Et}\right)=\mathrm{C}(\mathrm{Cl}) \mathrm{CO}_{2} \mathrm{Pr}^{\mathrm{i}}\right\}(\mathrm{CO}) \mathrm{Cl}_{2}\right]^{-}$, with a chlorine atom trans to the $\mathrm{Pt}-\mathrm{C} \sigma$-alkenyl bond. Moreover the $\mathrm{Pt}(1)-\mathrm{O}(1)$ distance $[2.118(5) \AA]$ is much larger than the $\operatorname{Pt}(2)-\mathrm{O}(3)$ distance $[2.017(5) \AA]$, in part due to the higher trans influence of the phosphine ligand compared to the terminal carbonyl. The former value is close to that found in similar metallacycles having a carbonylic oxygen: $2.131(10) \AA^{11}$ in $\left[\mathrm{Pt}\left\{\mathrm{CH}\left(\mathrm{CO}_{2} \mathrm{Me}\right) \mathrm{C}(\mathrm{COOMe})=\mathrm{CHMe}\right\}\left(\mathrm{PEt}_{3}\right)_{2}\right]^{+}$and $2.110(4) \AA^{13}$ in $\left[\mathrm{Pt}\left\{\mathrm{CMe}\left[\mathrm{CH}\left(\mathrm{CO}_{2} \mathrm{Me}\right) \mathrm{CH}(\mathrm{COOMe})\right]\right\}-\right.$ $\left.\left(\mathrm{PPh}_{3}\right)_{2}\right]^{+}$.

The bond distances involving the other ligands have the expected values; in particular, the short separations $\mathrm{Pt}(1)$ $\mathrm{P}[2.217(2) \AA]$ and $\mathrm{Pt}(2)-\mathrm{C}(7)[1.804(9) \AA]$ confirm the low trans influence of the oxygen atom. ${ }^{16}$ On the other hand, some interesting features are present in the organic fragment. The two $\mathrm{C}=\mathrm{O}$ distances $[1.26(1) \AA]$ are longer than expected for non-coordinated carbonyls ${ }^{5.6}$ and the same holds for the $\mathrm{C}(2)-\mathrm{C}(3)$ bond length. ${ }^{6,14}$ However the $\mathrm{C}=\mathrm{O}$ separation is only slightly larger than that of $1.24-1.25 \AA$ found for co-ordinated carbonyls, ${ }^{1,13}$ while the $\mathrm{C}(3)-\mathrm{C}(4)$ distance $[1.45(1) \AA]$ is shorter than $\mathrm{C}(3)-\mathrm{C}(6)[1.48(1) \AA]$, the value expected for a $\mathrm{C}\left(s p^{2}\right)-\mathrm{C}\left(s p^{2}\right)$ single bond. ${ }^{17}$ These differences from literature values are at the limit of significance, but when taken together the resulting trend suggests that some conjugation is present, involving in particular atoms $\mathrm{C}(2), \mathrm{C}(3), \mathrm{C}(4)$, and $\mathrm{O}(1)$ and $\mathrm{Pt}(1), \mathrm{C}(6), \mathrm{O}(3)$, and $\mathrm{Pt}(2)$. The spectral results, especially the i.r. and n.m.r. data, strongly support this conclusion (see below').

No short intermolecular contact is present and the molecules are held together by van der Waals forces.

Spectroscopic Measurements.-The i.r. and n.m.r. spectra of complex (2) are fully consistent with the solid-state structure. The i.r. spectrum clearly shows the presence of a carbonyl group terminally bonded to platinum $\left(2110 \mathrm{~cm}^{-1}\right)$, while there are no bands present in the $1750-1600 \mathrm{~cm}^{-1}$ region typical for uncoordinated carboxylate carbonyl groups; ${ }^{18}$ it is, however, impossible to assign the $\mathrm{CO}$ stretching frequency of the ester group co-ordinated to platinum $\left(1600-1450 \mathrm{~cm}^{-1}\right)^{4-6}$ because of the presence of other bands in this region.

The ${ }^{1} \mathrm{H}$ n.m.r. spectrum in $\mathrm{CDCl}_{3}$ consists of a pseudo-triplet at $\left.\left.\delta 2.58\left\{\mathrm{CH}_{3},{ }^{3} J^{195} \mathrm{Pt}(2)-\mathrm{H}\right)\right]=64 \mathrm{~Hz}\right\}$, a singlet at 4.2 $\left(\mathrm{OCH}_{3}\right)$, and a multiplet at $7.5\left(\mathrm{P}-\mathrm{C}_{6} \mathrm{H}_{5}\right)$ with the intensity ratio (1:1:5). The ${ }^{31} \mathrm{P}-\left\{{ }^{1} \mathrm{H}\right\}$ n.m.r. spectrum in $\mathrm{CDCl}_{3}$ shows a signal at $\delta 15.2$ which is coupled to both platinum atoms $\left.\left\{{ }^{1} J\left[{ }^{195} \mathrm{Pt}(1)-\mathrm{P}\right]=5015,{ }^{4} J^{195} \mathrm{Pt}(2)-\mathrm{P}\right]=52 \mathrm{~Hz}\right\}$.

The ${ }^{195} \mathrm{Pt}$ n.m.r. spectrum is complicated because of the presence of different isotopomers, due to the statistical dis- (a)

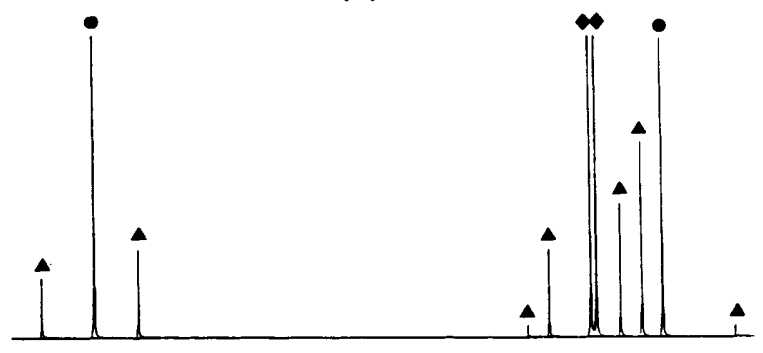

(b)

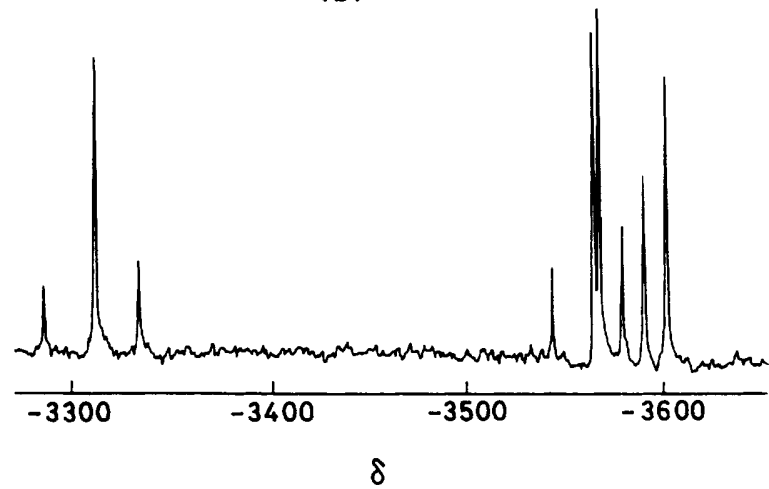

Figure 2. Simulated (a) [( ) ${ }^{195} \mathrm{Pt}(1)-\mathrm{Pt}(2),(-) \mathrm{Pt}(1)-{ }^{195} \mathrm{Pt}(2)$, and (A) ${ }^{195} \mathrm{Pt}(1)-{ }^{195} \mathrm{Pt}(2)$ isotopomers] and experimental $(b){ }^{195} \mathrm{Pt}$ n.m.r. spectra of complex (2)

tribution of platinum nuclei of spins 0 and $\frac{1}{2}$. The two isotopomers containing only one ${ }^{195} \mathrm{Pt}$ give a first-order spectrum and the isotopomer containing two ${ }^{195} \mathrm{Pt}$ nuclei gives rise to a secondorder spectrum because of ${ }^{195} \mathrm{Pt}(1)-{ }^{195} \mathrm{Pt}(2)$ coupling; this subspectrum therefore contains information about this coupling constant. In Figure 2 the simulated and experimental ${ }^{195} \mathrm{Pt}$ n.m.r. spectra are reported. The simulated spectrum was obtained by superimposing the three sub-spectra of isotopomers ${ }^{195} \mathrm{Pt}(1)-\mathrm{Pt}(2), \quad \mathrm{Pt}(1)-{ }^{195} \mathrm{Pt}(2)$, and ${ }^{195} \mathrm{Pt}(1)-{ }^{195} \mathrm{Pt}(2)$ with intensity ratio $2: 2: 1$. The simulated ${ }^{195} \mathrm{Pt}(1)-{ }^{195} \mathrm{Pt}(2)$ subspectrum was optimized by adjusting the coupling constant between $\mathrm{Pt}(1)$ and $\mathrm{Pt}(2)$. The value which fits the experimental spectrum is $\left.{ }^{3} J^{195} \mathrm{Pt}(1){ }^{195} \mathrm{Pt}(2)\right] 818 \mathrm{~Hz}$. Several ${ }^{1} J$ - and ${ }^{2} J$ (Pt-Pt) coupling constants are available but to our knowledge there are no data for three-bond couplings. ${ }^{19}$ The values found in the literature are scattered over a large range and they are not clearly rationalized. However a comparison of our ${ }^{3} J$ value of $818 \mathrm{~Hz}$ with other values reported indicates the high coupling between the two platinum atoms through the organic fragment. The planarity of the molecule and the electronic delocalization, suggested by the $X$-ray results, are important in rationalizing this high value.

On the basis of the results obtained for the phosphine derivative (2) it is possible to propose the structure of compound (1) [see Figure 2(b), where $\mathrm{PPh}_{3}$ is replaced by $\mathrm{CO}$ ]. Elemental analysis and spectroscopic data are in agreement with this formulation. In particular we note that: $(i)$ the coordination of the carbonyl groups found in complex (2) is already present in complex (1), as shown by the absence of bands around $1700 \mathrm{~cm}^{-1}$ in the i.r. spectrum; (ii) there is an almost quantitative evolution of carbon monoxide when (1) reacts with $\mathrm{PPh}_{3}$; (iii) the coupling constant of the methyl group with $\mathrm{Pt}(2)$ in the ${ }^{1} \mathrm{H}$ n.m.r. spectrum is similar for compounds (1) and (2) suggesting that the organic fragment is the same in both compounds; ( $i v$ ) the presence of platinum-chlorine bonds in (1) is confirmed by the i.r. spectrum; and $(v)$ there are two bands 
<smiles>CC#CC(=O)OC</smiles>

$\left[\mathrm{Pt}(\mathrm{CO})_{2} \mathrm{Cl}_{2}\right]+\mathrm{CO}+\mathrm{H}_{2} \mathrm{O}$

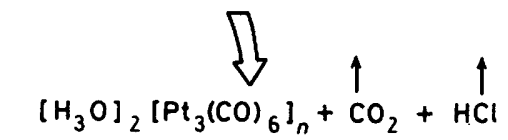

$y$<smiles>CC=C1C(=O)[P@](Cl)(C=O)OC1OC</smiles>

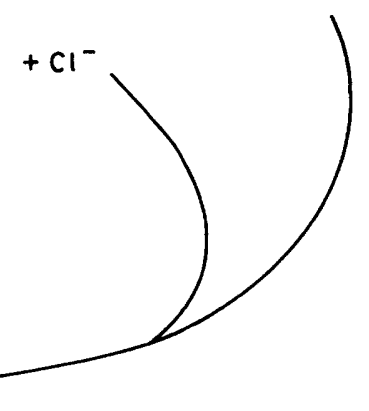<smiles></smiles>

(A)

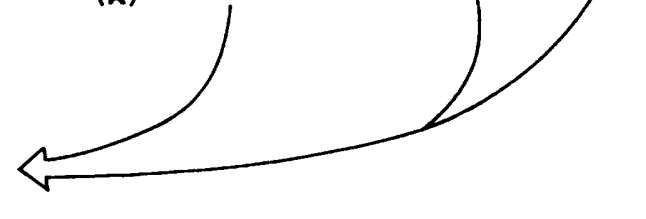

Scheme.

centred at $2135 \mathrm{~s} \mathrm{~cm}^{-1}$ which are essentially coincident in the i.r. spectrum of (1), suggesting that there are two carbonyl groups in a trans position to ligands with a similar trans influence; this is consistent with the same geometry around $\operatorname{Pt}(2)$ on going from (1) to (2).

\section{Conclusions}

The formation of complex (1) is not unexpected considering the related reactions of $\left[\mathrm{Pt}(\mathrm{CO})_{2} \mathrm{Cl}_{2}\right]$ with acetylenes ${ }^{4,5,8}$ and the previous work on the reduction of platinum(II) carbonyl complexes. ${ }^{10}$

A reasonable mechanism for the reaction between $\left[\mathrm{Pt}(\mathrm{CO})_{2^{-}}\right.$ $\mathrm{Cl}_{2}$ ] and methyl 2-butynoate to give (1) can be proposed (see Scheme). The positively charged carbonyl group of $\left[\mathrm{Pt}(\mathrm{CO})_{2}\right.$ $\mathrm{Cl}_{2}$ ] attacks the acetylene, in a Markownikoff manner, to give the cationic species (A), which is stabilized through chelation of the oxygen of the alkoxycarbonyl group to the platinum; this intermediate species reacts further with $\mathrm{Cl}^{-}$and $\left[\mathrm{Pt}_{3}(\mathrm{CO})_{6}\right]_{n}{ }^{2-}$, the reduction product in the reaction of $\left[\mathrm{Pt}(\mathrm{CO})_{2} \mathrm{Cl}_{2}\right]$ with $\mathrm{CO}$ and water. The co-ordination around $\mathrm{Pt}(2)$ is completed by formation of a second five-membered ring through the coordination of oxygen to $\mathrm{Pt}(1)$. We have reduced $\left[\mathrm{Pt}(\mathrm{CO})_{2} \mathrm{Cl}_{2}\right]$ to the dark precipitate $\left[\mathrm{Pt}_{3}(\mathrm{CO})_{6}\right]_{n}{ }^{2-}$ and successively treated this in a $\mathrm{CHCl}_{3}$ solution with $\left[\mathrm{Pt}(\mathrm{CO})_{2} \mathrm{Cl}_{2}\right]$ and $\mathrm{MeC} \equiv$ $\mathrm{CCO}_{2} \mathrm{Me}$. As expected, the yellow product (1) was obtained in quantitative yield.

\section{Experimental}

Microanalyses and molecular weights were determined by Laboratorio Analisi Universita' di Milano and by Pascher Mikroanalytisches Laboratorium Bonn. Proton n.m.r. spectra were recorded on a Bruker WP 80 or on a Varian XL-200 spectrometer and are reported as downfield from the internal standard $\mathrm{SiMe}_{4}$. The ${ }^{31} \mathrm{P}$ n.m.r. spectra were recorded on a Bruker WP 80 spectrometer operating at $32.4 \mathrm{MHz}$ and are reported downfield of the external standard $\left(85 \% \mathrm{H}_{3} \mathrm{PO}_{4}\right.$ in $\left.\mathrm{D}_{2} \mathrm{O}\right),{ }^{195} \mathrm{Pt}$ n.m.r. spectra on a Bruker WP 80 spectrometer operating at $17.2 \mathrm{MHz}$ (external standard $\mathrm{Na}_{2} \mathrm{PtCl}_{6}$; pulse angle $60^{\circ}$, delay $0.5 \mathrm{~s}$ ). For the ${ }^{31} \mathrm{P}$ and ${ }^{195} \mathrm{Pt}$ n.m.r. spectra the acquisition time was 0.4 and $0.5 \mathrm{~s}$, respectively. Spectral simulations were performed using the program PANIC 81 provided by the instrument manufacturer. Infrared spectra were recorded on a Perkin-Elmer 781 grating spectrophotometer

Table 2. Crystal data and intensity collection parameters for complex (2)
Formula:
$M$
Crystal system
Space group
$a / \AA$
$b / \AA$
$c / \AA$
$\alpha /^{\circ}$
$\beta /{ }^{\circ}$
$\gamma /^{\circ}$
$U / \AA^{3}$
$Z$
$F(000)$

$D_{\mathrm{c}} / \mathrm{g} \mathrm{cm}^{-3}$

Mo- $K_{\alpha}$ radiation (graphite monochromated, $\lambda=0.71069 \AA) \mu / \mathrm{cm}^{-1}$

$\theta$ range $/^{\circ}$

Scan type

Scan speed $/{ }^{\circ} \mathrm{s}^{-1}$

Scan width $/^{\circ}$

Total background time/s

Receiving aperture $/{ }^{\circ}$

$$
\begin{aligned}
& \text { horizontal } \\
& \text { vertical }
\end{aligned}
$$

No. of data collected

No. of obs. data $\left[I_{\text {net }}>3 \sigma(I)\right]$

$R^{a}$
$R^{\prime b}$

Goodness of fit, $S^{\mathbf{r}}$

${ }^{a} R=\Sigma|| F_{\mathrm{o}}|-| F_{\mathrm{c}}|| \Sigma\left|F_{\mathrm{o}}\right| . \quad{ }^{b} R^{\prime}=\left[\Sigma w\left(\left|F_{\mathrm{o}}\right|-\left|F_{\mathrm{c}}\right|\right)^{2} / \Sigma w\left|F_{\mathrm{o}}\right|^{2}\right]^{\frac{1}{2}} . \quad{ }^{c} S=$ $\left[\Sigma w\left(\left|F_{\mathrm{o}}\right|-\left|F_{\mathrm{c}}\right|\right)^{2} /(n-m)\right]^{\frac{1}{2}}$, where $n$ is the number of observations and $m$ the number of parameters.

calibrated with polystyrene film, or on a Nicolet MX-1 FT-IR Fourier-transform interferometer using Nujol mulls and $\mathrm{NaCl}$ or CsI plates.

All the reactions were conducted under carbon monoxide or nitrogen atmospheres using the Schlenk-tube technique and with anhydrous solvents. Chloroform containing $1 \%$ of EtOH was used without further purification, but degassed and kept under a nitrogen atmosphere. Solvents were purified and dried by standard methods. The complex cis- $\left[\mathrm{Pt}(\mathrm{CO})_{2} \mathrm{Cl}_{2}\right]$ was prepared as described previously. ${ }^{2}$ 
Table 3. Positional parameters with e.s.d.s in parentheses for complex (2)

\begin{tabular}{|c|c|c|c|c|c|c|c|}
\hline Atom & $X / a$ & $Y / b$ & $Z / c$ & Atom & $X / a$ & $Y / b$ & $Z / c$ \\
\hline $\operatorname{Pt}(1)$ & $0.25744(2)$ & $0.06950(3)$ & $0.04557(3)$ & $\mathrm{C}(13)$ & $0.3352(7)$ & $0.3332(9)$ & $-0.1962(10)$ \\
\hline $\operatorname{Pt}(2)$ & $0.00413(2)$ & $0.14564(4)$ & $-0.31164(4)$ & $\mathrm{C}(14)$ & $0.3159(5)$ & $0.4151(7)$ & $0.1255(8)$ \\
\hline $\mathrm{Cl}(1)$ & $0.3727(2)$ & $0.0099(2)$ & $0.2161(3)$ & $C(15)$ & $0.2299(6)$ & $0.4229(8)$ & $0.1752(9)$ \\
\hline $\mathrm{Cl}(2)$ & $0.0464(2)$ & $0.3539(3)$ & $-0.3452(3)$ & $C(16)$ & $0.2046(7)$ & $0.5508(9)$ & $0.2344(10)$ \\
\hline $\mathbf{P}$ & $0.3543(1)$ & $0.2512(2)$ & $0.0501(2)$ & $C(17)$ & $0.2633(7)$ & $0.6676(10)$ & $0.2456(11)$ \\
\hline$C(1)$ & $-0.1080(7)$ & $-0.1283(10)$ & $-0.3256(11)$ & $C(18)$ & $0.3489(7)$ & $0.6599(9)$ & $0.2000(10)$ \\
\hline $\mathrm{C}(2)$ & $-0.0162(6)$ & $-0.0221(8)$ & $-0.2571(9)$ & $C(19)$ & $0.3758(6)$ & $0.5332(8)$ & $0.1412(9)$ \\
\hline$C(3)$ & $0.0619(5)$ & $-0.0262(8)$ & $-0.1509(9)$ & $\mathrm{C}(20)$ & $0.4814(5)$ & $0.2757(7)$ & $0.1590(8)$ \\
\hline C(4) & $0.0810(6)$ & $-0.1279(8)$ & $-0.0802(9)$ & $\mathrm{C}(21)$ & $0.4976(6)$ & $0.3252(8)$ & $0.3091(9)$ \\
\hline$C(5)$ & $0.0437(7)$ & $-0.3397(9)$ & $-0.0449(10)$ & $C(22)$ & $0.5930(7)$ & $0.3483(10)$ & $0.4006(12)$ \\
\hline$C(6)$ & $0.1457(5)$ & $0.0882(7)$ & $-0.1001(8)$ & $\mathrm{C}(23)$ & $0.6717(8)$ & $0.3192(11)$ & $0.3395(12)$ \\
\hline$C(7)$ & $-0.1098(7)$ & $0.1090(10)$ & $-0.4542(11)$ & $C(24)$ & $0.6565(8)$ & $0.2695(10)$ & $0.1918(12)$ \\
\hline$C(8)$ & $0.3615(5)$ & $0.2350(7)$ & $-0.1339(8)$ & $\mathrm{C}(25)$ & $0.5616(6)$ & $0.2487(9)$ & $0.0994(10)$ \\
\hline $\mathrm{C}(9)$ & $0.3910(6)$ & $0.1188(9)$ & $-0.2110(10)$ & $O(1)$ & $0.1606(4)$ & $-0.1097(5)$ & $0.0167(6)$ \\
\hline$C(10)$ & $0.3964(7)$ & $0.0996(10)$ & $-0.3555(11)$ & $O(2)$ & $0.0158(4)$ & $-0.2385(6)$ & $-0.1170(7)$ \\
\hline$C(11)$ & $0.3703(8)$ & $0.1984(11)$ & $-0.4163(13)$ & $\mathrm{O}(3)$ & $0.1324(4)$ & $0.1819(5)$ & $-0.1550(6)$ \\
\hline$C(12)$ & $0.3409(7)$ & $0.3109(11)$ & $-0.3405(12)$ & $\mathrm{O}(4)$ & $-0.1801(6)$ & $0.0870(8)$ & $-0.5500(9)$ \\
\hline
\end{tabular}

\section{Syntheses. $-[\mathrm{Cl}(\mathrm{CO}) \mathrm{Pt}\{\mathrm{CMe}=\mathrm{C}(\mathrm{COOMe}) \mathrm{C}(=\mathrm{O})\} \mathrm{Pt}(\mathrm{CO})$ -}

Cl] (1). A solution of $\left[\mathrm{Pt}(\mathrm{CO})_{2} \mathrm{Cl}_{2}\right](2.27 \mathrm{~g}, 7.05 \mathrm{mmol})$ in $\mathrm{CHCl}_{3}\left(100 \mathrm{~cm}^{3}\right)$, under a stream of carbon monoxide, was treated with water $\left(0.2 \mathrm{~cm}^{3}, 11.1 \mathrm{mmol}\right)$ and the solution stirred for $10 \mathrm{~min}$ to give a dark precipitate of $\left[\mathrm{H}_{3} \mathrm{O}\right]_{2}\left[\mathrm{Pt}_{3}(\mathrm{CO})_{6}\right]_{n}$. Methyl 2-butynoate $\left(0.75 \mathrm{~cm}^{3}, 7.6 \mathrm{mmol}\right)$ was added and the suspension stirred, resulting in the disappearance of $\left[\mathrm{H}_{3} \mathrm{O}\right]_{2^{-}}$ $\left[\mathrm{Pt}_{3}(\mathrm{CO})_{6}\right]_{n}$ and the formation of a yellow precipitate (about 6 h). The reaction was monitored by i.r. spectroscopy, by checking the disappearance of $\left[\mathrm{Pt}(\mathrm{CO})_{2} \mathrm{Cl}_{2}\right]\left(2140 \mathrm{~s}\right.$ and $\left.2180 \mathrm{~s} \mathrm{~cm}^{-1}\right)$. The yellow solid was filtered off, washed with $\mathrm{CHCl}_{3}(3 \times 20$ $\left.\mathrm{cm}^{3}\right)$ and hexane $\left(3 \times 10 \mathrm{~cm}^{3}\right)$, and dried; yield $1.16 \mathrm{~g}(51 \%)$ (Found: $\mathrm{C}, 14.4 ; \mathrm{H}, 0.9 ; \mathrm{Cl}, 11.1 ; \mathrm{O}, 12.0 ; \mathrm{Pt}, 60.1$. Calc. for $\mathrm{C}_{8} \mathrm{H}_{6} \mathrm{Cl}_{2} \mathrm{O}_{5} \mathrm{Pt}_{2}: \mathrm{C}, 14.9 ; \mathrm{H}, 0.9 ; \mathrm{Cl}, 11.0 ; \mathrm{O}, 12.4 ; \mathrm{Pt}, 60.6 \%$ ). I.r. (Nujol mull): $2135[\mathrm{v}(\mathrm{CO})$ terminal $] 322 \mathrm{~cm}^{-1}[\mathrm{v}(\mathrm{Pt}-\mathrm{Cl})$ terminal]. ${ }^{1} \mathrm{H}$ N.m.r.: $\delta$ 4.32(s) $\left(\mathrm{OCH}_{3}\right)$ and $2.82\left\{\mathrm{CH}_{3}\right.$, $\left.{ }^{3} J[\mathrm{Pt}(2)-\mathrm{H}]=60.4 \mathrm{~Hz}\right\}$.

The mother-liquor was treated with $\left[\mathrm{N}\left(\mathrm{PPh}_{3}\right)_{2}\right] \mathrm{Cl}(1 \mathrm{~g})$ then concentrated to dryness; the residue when treated with 2propanol yielded the pale yellow solid $\left[\mathrm{N}\left(\mathrm{PPh}_{3}\right)_{2}\right]\left[\mathrm{Pt}(\mathrm{CO}) \mathrm{Cl}_{3}\right]$ $\left\{40 \%\right.$ based on $\left.\left[\mathrm{Pt}(\mathrm{CO})_{2} \mathrm{Cl}_{2}\right]\right\}$.

$$
\left[\mathrm{Cl}(\mathrm{CO}) \mathrm{Pt}\{\mathrm{CMe}=\mathrm{C}(\mathrm{COOMe}) \mathrm{C}(=\mathrm{O})\} \mathrm{PtCl}\left(\mathrm{PPh}_{3}\right)\right] \text { (2).To a }
$$

suspension of complex (1) $(0.445 \mathrm{~g}, 0.69 \mathrm{mmol})$ in anhydrous thf $\left(30 \mathrm{~cm}^{3}\right)$ under a nitrogen atmosphere was added a solution of $\mathrm{PPh}_{3}(0.165 \mathrm{~g}, 0.69 \mathrm{mmol})$ in thf $\left(5 \mathrm{~cm}^{3}\right)$. An immediate evolution of $\mathrm{CO}$ was noted and a clear yellow solution was obtained. By concentration to a small volume, a pale yellow precipitate was formed; after cooling the yellow solid was filtered off, washed with cold thf $\left(2 \times 2 \mathrm{~cm}^{3}\right)$, and dried. Yield of complex (2) $0.64 \mathrm{~g} \mathrm{(90 \% )} \mathrm{(Found:} \mathrm{C,} \mathrm{34.3;} \mathrm{H,} \mathrm{2.8;} \mathrm{Cl,} \mathrm{8.2;} \mathrm{P,} \mathrm{3.5;}$ $\mathrm{Pt}$, 44.2. Calc. for $\mathrm{C}_{25} \mathrm{H}_{21} \mathrm{Cl}_{2} \mathrm{O}_{4} \mathrm{PPt}_{2}$ : C, 34.2; $\mathrm{H}, 2.4 ; \mathrm{Cl}, 8.1 ; \mathrm{P}$, $3.5 ; \mathrm{Pt}, 44.4 \%$ ). An almost quantitative amount of carbon monoxide was collected over mercury $\left[15.8 \mathrm{~cm}^{3}\right.$ at $22{ }^{\circ} \mathrm{C}$ and 1 atm $(101325 \mathrm{~Pa}), 95 \%$ ].

N.m.r.: $\left.{ }^{1} \mathrm{H}, \delta 2.58\left\{\mathrm{CH}_{3},{ }^{3} J \mathrm{Pt}(2)-\mathrm{H}\right]=63.8\right\}, 4.2\left(\mathrm{~s}, \mathrm{OCH}_{3}\right)$, and $7--8\left(\mathrm{~m}, \mathrm{C}_{6} \mathrm{H}_{5}\right) ;{ }^{31} \mathrm{P}, \delta 15.2\left\{{ }^{1} J\left[{ }^{195} \mathrm{Pt}(1)-\mathrm{P}\right]=5015\right.$, $\left.{ }^{4} \int[\mathrm{Pt}(2)-\mathrm{P}]=52\right\} ;{ }^{195} \mathrm{Pt}, \delta[\mathrm{Pt}(1)]-3456\left[\mathrm{~d},{ }^{1} J\left({ }^{31} \mathrm{P}-\right.\right.$ $\left.\left.{ }^{195} \mathrm{Pt}\right)=5015\right]$ and $\delta[\mathrm{Pt}(2)]-3566\left\{\mathrm{~d},{ }^{4} J\left[{ }^{31} \mathrm{P}-{ }^{195} \mathrm{Pt}(1)\right]=\right.$ $\left.52,{ }^{3} J\left[{ }^{195} \mathrm{Pt}(1)-{ }^{195} \mathrm{Pt}(2)\right]=818 \mathrm{~Hz}\right\}$. Molecular weight: found 860 (vapour pressure; $3.7537 \mathrm{mg}$ in $0.7738 \mathrm{~g} \mathrm{CHCl}_{3}$ ); calc. 877.5.

Crystallography.-Pale yellow crystals of complex (2) suitable for $X$-ray diffraction and having a prismatic habit were obtained by slow diffusion of hexane into dichloromethane solutions. A single crystal of approximate dimensions $0.2 \times$ $0.1 \times 0.05 \mathrm{~mm}$ was mounted on a glass fibre on a Philips PW 1100 automated diffractometer and used for the analysis at room temperature. Cell constants were obtained by a leastsquares fit of 22 accurately centred reflections having $28 \leqslant$ $2 \theta \leqslant 36^{\circ}$. Three standard reflections $(4-42,-44-2,-37$ $-5)$ were monitored every $2 h$ to test the stability of the crystal and the experimental set-up: no significant variation was detected. Cell constants and data collection conditions are reported in Table 2. Data were corrected for Lorentz and polarization factors and for absorption using azimuthal $\psi$ scans of reflections $-43-1,-76-2$, and $-86-2$.

The structure was solved by Patterson and Fourier methods and refined by blocked full matrix with anisotropic thermal parameters for $\mathrm{Pt}, \mathrm{Cl}$, and $\mathrm{P}$ atoms. The contribution of the $\mathrm{H}$ atoms in calculated positions $(\mathrm{C}-\mathrm{H} 1.08 \AA$ ) was taken into account in the last stages of the refinement and their isotropic thermal parameters were refined in two groups: hydrogens in the organic moiety and hydrogens in the phosphine ligand, with final values $B=9.8(8)$ and $7.4(6) \AA^{2}$, respectively. Upon convergence (largest shift $\Delta / \sigma=0.14$ ) the final Fourier difference map did not show any significant feature [the largest peak, ca. 0.8 e $\AA^{-3}$, was located about midway between $\operatorname{Pt}(2)$ and $\mathrm{Cl}(2)]$. The function minimized was $\Sigma w\left(\left|F_{\mathrm{o}}\right|-\left|F_{\mathrm{c}}\right|\right)^{2}$ with weights $w=k /\left[\sigma^{2}\left(F_{\mathrm{o}}\right)+g\left|F_{\mathrm{o}}\right|^{2}\right](k=2.0504, g=0.000229)$.

Atomic scattering factors, corrected for the real and the imaginary part of atomic dispersion, were taken from ref. 20. Solution and refinement of the structure was carried out with the SHELX package of programs ${ }^{21}$ and geometrical calculations with the program PARST. ${ }^{22}$ Final atomic co-ordinates for non- $\mathrm{H}$ atoms are reported in Table 3 .

\section{Acknowledgements}

We thank the Italian C.N.R. for the opportunity to use the equipment and Ministero Pubblica Istruzione for financial support.

\section{References}

1 Part 9, L. Garlaschelli, M. C. Malatesta, S. Panzeri, A. Albinati, and F. Ganazzoli, Organometallics, 1987, 9, 63.

2 F. Canziani, P. Chini, A. Quarta, and A. Di Martino, J. Organomet. Chem., 1971, 26, 285.

3 F. Canziani and M. C. Malatesta, J. Organomet. Chem., 1975, 90, 233.

4 F. Canziani, L. Garlaschelli, and M. C. Malatesta, J. Organomet. Chem., 1978, 146, 179. 
5 F. Canziani, A. Albinati, L. Garlaschelli, and M. C. Malatesta, J. Organomet. Chem., 1978, 146, 197.

6 F. Canziani, L. Garlaschelli, M. C. Malatesta, and A. Albinati, J. Chem. Soc., Dalton Trans., 1981, 2395.

7 F. Canziani, F. Galimberti, L. Garlaschelli, M. C. Malatesta, and A. Albinati, Gazz. Chim. Ital., 1982, 112, 323.

8 F. Canziani, F. Galimberti, L. Garlaschelli, M. C. Malatesta, A. Albinati, and F. Ganazzoli, J. Chem. Soc., Dalton Trans., 1983, 827.

9 F. Canziani, C. Allevi, L. Garlaschelli, M. C. Malatesta, A. Albinati, and F. Ganazzoli, J. Chem. Soc., Dalton Trans., 1984, 2637.

10 G. Longoni and P. Chini, J. Am. Chem. Soc., 1976, 98, 7225.

11 C. P. Brock and T. G. Attig, J. Am. Chem. Soc., 1980, 102, 1319.

12 A. T. Hutton, D. M. McEwan, B. L. Shaw, and S. W. Wilkinson, J. Chem. Soc., Dalton Trans., 1983, 2011.

13 T. G. Attig, R. J. Ziegler, and C. P. Brock, Inorg. Chem., 1980, 19, 2315.

14 C. Anklin, P. S. Pregosin, F. Bachechi, P. Mura, and L. Zambonelli, J. Organomet. Chem., 1981, 222, 175.

15 C. J. Cardin and K. W. Muir, J. Chem. Soc., Dalton Trans., 1977, 1593.
16 J. K. Burdett, 'Molecular Shapes,' Wiley, New York, 1980, ch. 12.

17 See, for example, R. Allmann, in 'The Chemistry of the Hydrazo, Azo and Azoxy groups,' ed. S. Patai, Wiley-Interscience, New York, 1975, pp. 23-52.

18 K. Nakanishi, 'Infrared Absorption Spectroscopy,' Holden-Day, San Francisco, 1966.

19 P. S. Pregosin, Coord. Chem. Rev., 1982, 44, 247; Annu. Rep. NMR Spectrosc., 1986, 17, 285.

20 'International Tables for $X$-Ray Crystallography,' Kynoch Press, Birmingham, 1974.

21 G. M. Sheldrick, SHELX 76 Program for Crystal Structure Determination, University of Cambridge, 1976.

22 M. Nardelli, PARST, A system of computer routines for calculating molecular parameters from the results of crystal structure analysis, Universita' di Parma, 1982.

Received 14th November 1986; Paper 6/2203 